1

\title{
Estimating the Probability of Fish Encountering a Marine Hydrokinetic Device
}

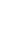

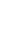 \\ Haixue Shen, Gayle Barbin Zydlewski*, Haley A. Viehman, Garrett Staines \\ School of Marine Sciences, University of Maine, Orono, ME 04469-5741, USA \\ * Corresponding author \\ Tel: $207-581-4365$ \\ Fax: 207-581-4990 \\ E-mail address: gayle.zydlewski@maine.edu
}

\section{Abstract}

Strong tidal currents in eastern Maine, USA, make that region attractive for tidal power development. Little is known about the effects of marine hydrokinetic (MHK) devices on fish, yet many fish species use tidal currents for movements. We used empirical data from stationary and mobile hydroacoustic surveys to examine the probability that fish would be at the depth of an MHK device and may therefore encounter it. The probability was estimated using three components: 1) probability of fish being at device-depth when the device was absent;2) probability of fish behavior changing to avoid the device in the far-field; and 3) probability of fish being at device-depth in the near-field when the device was present. There were differences in probabilities of fish encountering the MHK device based on month, diel condition and tidal stage. The maximum probability of fish encountering the whole device was 0.432 (95\% CI: [0.305, 0.553]), and the probability of fish encountering only device foils was 0.058 (95\% CI: $[0.043,0.073])$. Mobile hydroacoustics indicated that fish likely avoided the device with horizontal movement beginning 140 m away. We estimated the encounter probability for one device, but results can be applied to arrays, which may have bay-wide implications.

\section{Keywords:}

Fish, Tidal energy, MHK device, Hydroacoustics, Encounter probability, Bayesian Generalized Linear Model 


\section{Introduction}

Tidal power projects are being developed around the world in recent years to harness this predictable, regular and renewable energy from ocean currents [1-4]. Large, in-stream marine hydrokinetic (MHK) devices can be used to generate electricity from the kinetic energy of fast-flowing water using moving device foils [5-7]. Unlike barrage tidal power generation and tidal fences, which block off a channel, MHK devices are free-standing, open structures that are expected to be an environmentally sound tidal power option. The open configuration and relatively slow movement of MHK devices allow fish, water, and sediment to pass through the channel and provide opportunities for fish to avoid the areas of the device(s) [8-10].

Tidal currents play an important role in the life cycles of many fish species in estuaries and coastal ocean waters. By changing vertical position in the water column, migratory species can use tidal flow to access suitable foraging, spawning, and sheltering grounds [11-13]. The tidal currents provide an energetic advantage for directed movements between habitats [14-16]. Devices may sufficiently alter water flow patterns or other features to influence the behavior of fish using the tidal currents if there is spatial overlap between fish and MHK devices $[6,8,17]$. Effects on behavior may include interference with migration, habitat selection, and avoidance or evasion of individuals due to foil strike $[4,17,18]$. Concerns have been raised regarding the risk of foil strike to fish because some devices have foil-tip velocities exceeding $10 \mathrm{~m} \cdot \mathrm{s}^{-1}$ [19]. Although some studies have examined the survival of fish passing through tidal devices in laboratory flumes $[9,10,18]$, little empirical data have been collected that directly document interactions between fish and MHK devices $[4,19,20]$. Thus, different quantitative models have been explored to model fish interactions with MHK devices [6,10,19,21,22]. Wilson et al. [21] used predator-prey interaction to predict the encounter rate of herring with MHK devices. A mark-recapture model was used to assess the survival rate for three riverine species [10]. More complicated models have been developed to cover different aspects of fish interactions with MHK devices [19,22], including interactions of certain species (e.g., sturgeon [22]) and interactions of different assemblages with a device [19]. Romero-Gomez and Richmond [6] first modeled the flow and turbulence characteristics around an MHK device and then simulated flow conditions in a Lagrangian 52 particle model and estimated fish survival at $96.7-99.1 \%$. They determined that fish collision with a foil was dependent on fish size and turbulence resolution in the model. 
deployed. To date, two devices have been tested in Cobscook Bay, Maine, the eastern-most bay of the USA, which opens into the Bay of Fundy. The mean tidal range is $5.7 \mathrm{~m}$ in Cobscook Bay [23] and current speed can exceed 2 $\mathrm{m} \cdot \mathrm{s}^{-1}$ in the channel of the outer bay. Ocean Renewable Power Company, LLC (ORPC) has taken a sequential approach to developing tidal power in this region and conducted initial test deployment of two MHK devices: TidGen $^{\circledR}$ and OCGen ${ }^{\circledR}$. Deployment of these test devices provided the opportunity to investigate fish responses to MHK devices and to estimate the probability of fish encountering a single MHK device.

The dynamic environment at tidal power sites presents new challenges for monitoring the physical and biological characteristics around MHK devices. The extreme turbulence and sediment-laden water impair optical visibility, which reduces the effective use of camera or video monitoring techniques [20,24,25]. The strong tidal flows make the use of standard biological sampling tools such as nets and trawls difficult and dangerous. Passive acoustic telemetry has been used in such environments to monitor behavior of individuals of certain species such as striped bass (Morone saxatilis) [26] and Atlantic sturgeon (Acipenser oxyrinchus oxyrinchus) [22]. However, most tidal power sites have high levels of background noise from high flows, which limit detection due to the reduced efficiency of acoustic telemetry systems [26]. Hydroacoustic techniques have been successfully used to sample these high-velocity areas [7,27-29]. Nearly the entire water column can be sampled continuously using hydroacoustics, and the technique is less invasive to animals than other methods, such as trawling and tagging [30].

The probability that fish will encounter an MHK device located at a fixed depth depends on the natural distribution of fish in the water column. Fish vertical distribution has rarely been examined in strong tidal regions

74 [7], and more typically investigated in regions with little or moderate currents [31-33], lakes [34], and rivers [35].

These studies demonstrated that the vertical distribution of fish depends on natural variations, e.g., year, month, tidal stage, diel condition, and location. Significant diel or tidal differences in fish vertical distribution have been documented by several studies [7,32,35], with additional variation related to time of year, location, and species [7,32]. Fish may detect changing hydrodynamics based on device presence and operation, device noise from the moving foils, or visually identify the structure, thereby initiate a deterring or attracting response to the MHK device

80 [17]. Due to the complex nature of fish behavior, previous studies have not modeled avoidance in detail or included 81 avoidance in modeled estimates of fish collision with MHK devices [6,21]. Although Hammar et al. [19] included fish behavior in their probabilistic model, there are no available empirical data for model validation. The lack of empirical data makes it difficult to quantify fish avoidance of devices in an open marine environment. 
In this study, we aimed to estimate the probability of fish being at the same depth as (i.e., potentially

encountering) an MHK device. Empirical data were collected using hydroacoustic techniques before, during, and after ORPC deployed two devices at the Cobscook Bay Tidal Energy Project (CBTEP) area during 2011-2014. Mobile hydroacoustic surveys were conducted to explicitly estimate the avoidance of fish as they approach a device. Stationary hydroacoustic surveys were carried out to estimate the vertical distributions of fish at the project area. Empirical data collected from two hydroacoustic surveys were combined to estimate the probability of fish encountering an MHK device.

\section{Methods}

\subsection{Pilot MHK devices}

Two devices were deployed by ORPC during different periods: TidGen ${ }^{\circledR}$ from March 2012 to July 2013, and OCGen $^{\circledR}$ from July 2014 to August 2014 (Fig. 1). The entire TidGen ${ }^{\circledR}$ (bottom support structure and device foils) was $31.2 \mathrm{~m}$ long, $15.2 \mathrm{~m}$ wide, and $9.5 \mathrm{~m}$ high, and was bottom-mounted using a solid steel frame. The foils of the TidGen ${ }^{\circledR}$ were $6.7-9.5 \mathrm{~m}$ above the seafloor (Fig.1). Unlike the TidGen ${ }^{\circledR}$, the OCGen ${ }^{\circledR}$ was moored to the seafloor with gravity anchors and cable (Fig. 1). The entire OCGen $^{\circledR}$ (the float and foils) was $19.7 \mathrm{~m}$ long and $5.1 \mathrm{~m}$ high. The foils were located 8.0 to $10.5 \mathrm{~m}$ above the seafloor at slack tide. The depth of the OCGen ${ }^{\circledR}$ changed slightly with the current flow due to horizontal displacement, and foils were 5.9 to $7.4 \mathrm{~m}$ above the seafloor during maximum flow. The OCGen ${ }^{\circledR}$ can be displaced horizontally approximately $6.8 \mathrm{~m}$ from its neutral position during maximum flow. The two MHK devices had similar device foil designs (Gorlov helical design). The TidGen ${ }^{\circledR}$ had four sets of foils, while the OCGen ${ }^{\circledR}$ had two (Fig. 1). 
TidGen $^{\circledR}$

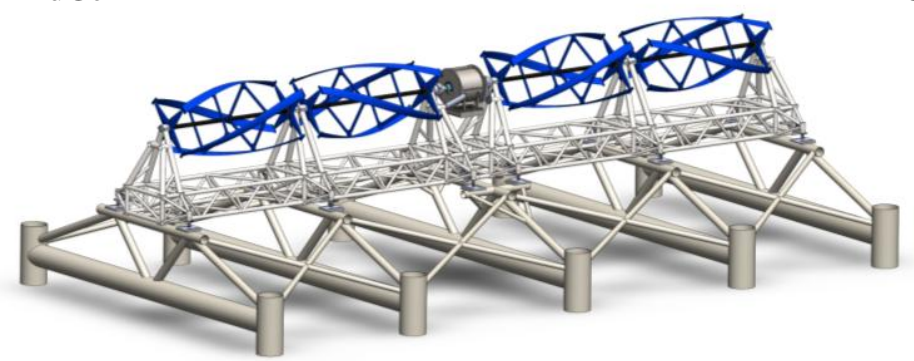

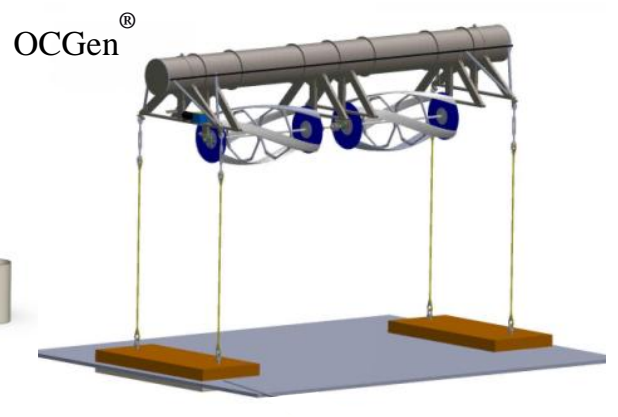

106

107

108

109

110

111

112

113

114

115

116

117

118

119

120

121

122

123

Fig. 1. Schematic representation of the TidGen ${ }^{\circledR}$ (length: $31.2 \mathrm{~m}$; width: $15.2 \mathrm{~m}$; height: $9.5 \mathrm{~m}$ ) and OCGen ${ }^{\circledR}$ (length: 19.7 m; width: 5.3 m; height: $5.1 \mathrm{~m}$ ) power systems of Ocean Renewable Power Company installed in outer Cobscook Bay, Maine.

\subsection{Study region}

During 2011-2013, stationary down-looking hydroacoustic surveys were conducted to monitor relative fish density and vertical distribution over time at the site of the TidGen ${ }^{\circledR}$ device in outer Cobscook Bay $\left(44^{\circ} 54.60^{\prime} \mathrm{N}\right.$, $\left.67^{\circ} 2.74^{\prime} \mathrm{W}\right)$, and at a control site $\left(44^{\circ} 54.04^{\prime} \mathrm{N}, 67^{\circ} 1.71^{\prime} \mathrm{W}\right)$ about $1.6 \mathrm{~km}$ seaward from the project site (Fig. 2; also,[7]). The control site allowed the differentiation of effects of the MHK devices from natural variation [7]. The water depth at the project site averaged $24.5 \mathrm{~m}$ at low tide and $32.3 \mathrm{~m}$ at high tide. At the control site, the water depth averaged $33.8 \mathrm{~m}$ at low tide and $41.3 \mathrm{~m}$ at high tide. The current speeds were generally less than $2 \mathrm{~m} \cdot \mathrm{s}^{-1}$, with a maximum speed of $2.5 \mathrm{~m} \cdot \mathrm{s}^{-1}$. The TidGen ${ }^{\circledR}$ stopped functioning in April 2013 and ORPC removed the foils and generator, leaving the bottom support frame. As such, mobile hydroacoustic surveys were carried out over and around the OCGen ${ }^{\circledR}$ in August 2014. The center location of the OCGen ${ }^{\circledR}\left(44^{\circ} 54.58^{\prime} \mathrm{N}, 67^{\circ} 2.68^{\prime} \mathrm{W}\right)$ was about 100 $\mathrm{m}$ seaward from the center location of the $\operatorname{TidGen}^{\circledR}$ bottom support frame. 


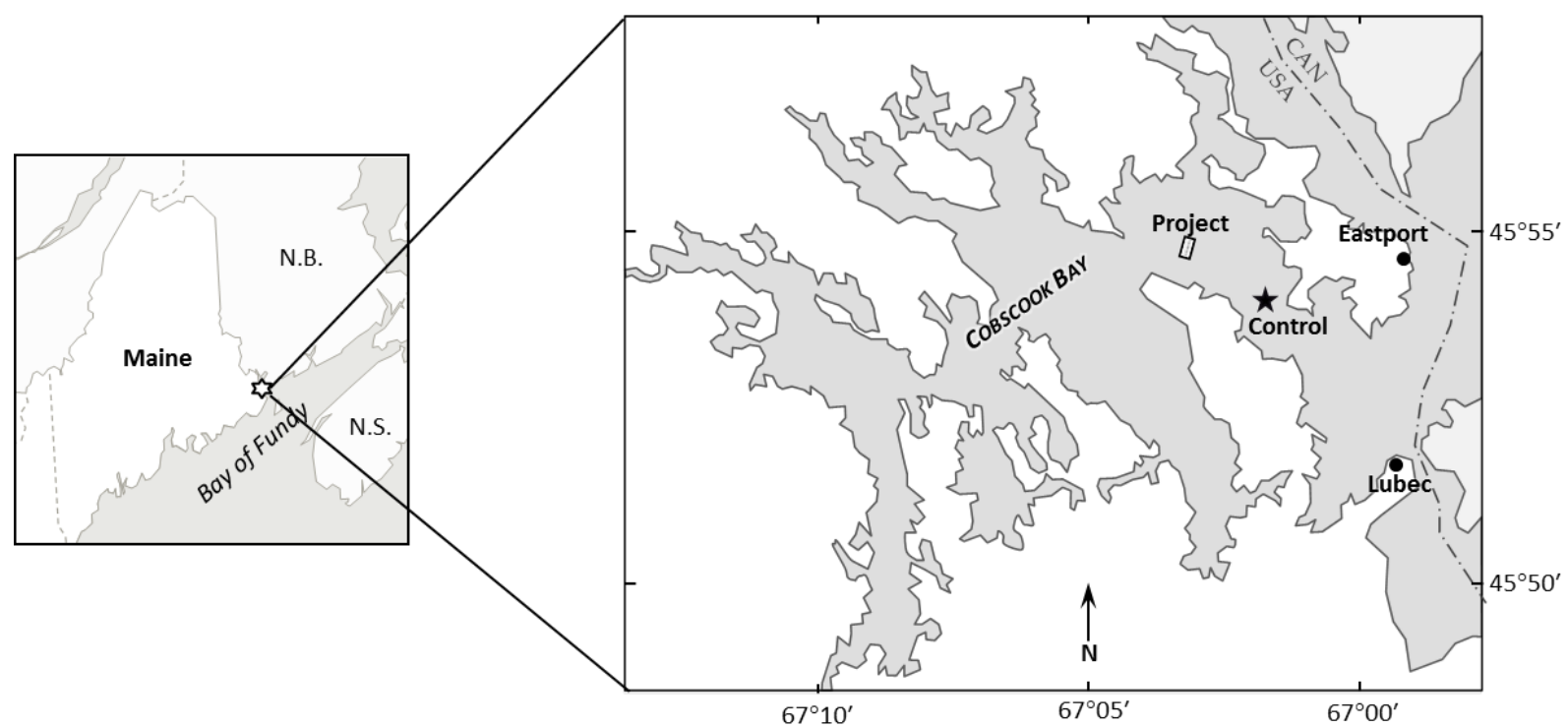

Fig. 2. Map of Cobscook Bay, Maine with locations of the project and control sites for fish-MHK interaction research.

\subsection{Stationary down-looking hydroacoustics}

From 2011 to 2013, stationary down-looking hydroacoustic surveys were conducted at the project and control sites on or near neap tides during multiple months (March, May, June, August, September, and November). After March 2013, ORPC operations around the $\operatorname{TidGen}^{\circledR}$ prevented hydroacoustic surveys at the project site, so following surveys were only conducted at the control site. In each month, 24-h surveys were conducted to cover diel and tidal variation in fish abundance and vertical distribution. Before and during the time that the first device (TidGen ${ }^{\circledR}$ ) was deployed at the project site, stationary down-looking surveys were carried out from a boat moored approximately $100 \mathrm{~m}$ from the device location. The boat moved approximately $50-100 \mathrm{~m}$ around the mooring point.

Hydroacoustic data were collected with a single-beam Simrad ES60 echosounder mounted $1 \mathrm{~m}$ below the surface, facing downward. The echosounder had a circular transducer (Simrad 38/200 CombiW) with a half-power beam angle of $31^{\circ}$, operating at $200 \mathrm{kHz}$ and $38 \mathrm{kHz}$ simultaneously at a rate of 2 pings. $\mathrm{s}^{-1}$ and pulse duration of $0.512 \mathrm{~ms}$. In each year, on-axis calibrations were carried out in winter on a frozen lake using copper calibration spheres (13.7mm diameter with $-45 \mathrm{~dB}$ nominal target strength, TS, for $200 \mathrm{kHz}$; 60-mm diameter with $-33.6 \mathrm{~dB}$ nominal TS for $38 \mathrm{kHz}$ ) [36]. During surveys, current speed was recorded every 30 minutes using an Acoustic Doppler Current Profiler (ADCP), which was also mounted $1 \mathrm{~m}$ below the surface. 

collected with the $200-\mathrm{kHz}$ frequency. General processing included the following steps. Calibration values were applied to the raw data and the upper $10 \mathrm{~m}$ of the water column were excluded because entrained air caused acoustic interference. The Echoview bottom-line-pick algorithm was used to automatically detect a bottom line, which was manually corrected for errors and offset upward by $0.5 \mathrm{~m}$. Any spike noise (e.g. noise from the ADCP) was removed and replaced by the signal from neighboring pings. Background noise was removed, and echograms were visually scrutinized to remove any interference from surface or other sources (e.g. nearby vessel echosounders, cables and boat noise). To exclude hydroacoustic signals from unwanted targets (such as plankton, krill and fish larvae), a TS threshold was set to $-60 \mathrm{~dB}$. Finally, the echogram was divided into cells spanning $30 \mathrm{~min}$ in time and $1 \mathrm{~m}$ in depth. For each cell, the area backscattering coefficient $\left(s_{\mathrm{a}}\right)$, which is proportional to fish density [30,36], was exported for analysis. rotating when the current speed falls below $0.5 \mathrm{~m} \cdot \mathrm{s}^{-1}$. The current speed data, collected with ADCP each half hour, were used to determine when the slack tides occurred. To standardize the comparisons between the project and control sites, only data from the lower $15 \mathrm{~m}$ of the water column were used to investigate fish vertical distribution because fish distributions were bottom-oriented in most months [7] and the TidGen ${ }^{\circledR}$ was located at a fixed distance above the bottom. Since fish distributions were bottom-oriented, comparisons were less likely to be affected by excluding different amounts of surface water at project and control sites [7]. Viehman et al. [7] successfully used data collected in 2010 and 2011 to compare fish distribution in lower $15 \mathrm{~m}$ and demonstrated that the control site provides a reference for monitoring fish presence in the region of and at the depth spanned by the MHK device.

\subsection{Mobile down-looking hydroacoustics}

Mobile hydroacoustic surveys near the $\mathrm{OCGen}^{\circledR}$ were used to observe fish behavior as they approached the device (Fig. 3). In summer 2014, a Simrad EK60 split-beam echosounder was used to conduct mobile hydroacoustic surveys around the OCGen ${ }^{\circledR}$. The echosounder used a circular transducer with a half-power beam angle of $7^{\circ}$, operating at $200 \mathrm{kHz}$ and 5 pings $\cdot \mathrm{s}^{-1}$, mounted $0.62 \mathrm{~m}$ below the surface, facing downward. This frequency is

171 beyond the hearing range of Atlantic herring $(\sim 10 \mathrm{kHz})$ [51], which are likely the most sound-sensitive species 
present in our study region [44]. Thus fish behavior should not be affected by the echosounder. Before each survey,

173

174

175

176

177 the echosounder was calibrated using a copper calibration sphere of $13.7-\mathrm{mm}$ diameter with $-45 \mathrm{~dB}$ nominal TS [36]. The mobile down-looking hydroacoustic surveys involved transects in which the boat drifted with the current (with the engine not in gear) from $200 \mathrm{~m}$ upstream to $200 \mathrm{~m}$ downstream of the OCGen ${ }^{\circledR}$. Boat direction was maintained with minor steering and throttle adjustments as needed. Mobile surveys were conducted on neap tide, carried out during 10 sequential flood tides and 4 ebb tides over 5 continuous days, with more than 20 transects conducted during each tide. One-third of transects were not over the OCGen ${ }^{\circledR}$ in order to be used as control transects. Only data collected during flood tides were used in the following analysis because the TidGen ${ }^{\circledR}$ bottom support frame affected fish behavior when they approached the OCGen ${ }^{\circledR}$ during ebb tides (Fig. 3). Water velocity data were collected continuously by ORPC using a bottom mounted ADCP adjacent to the OCGen ${ }^{\circledR}$.

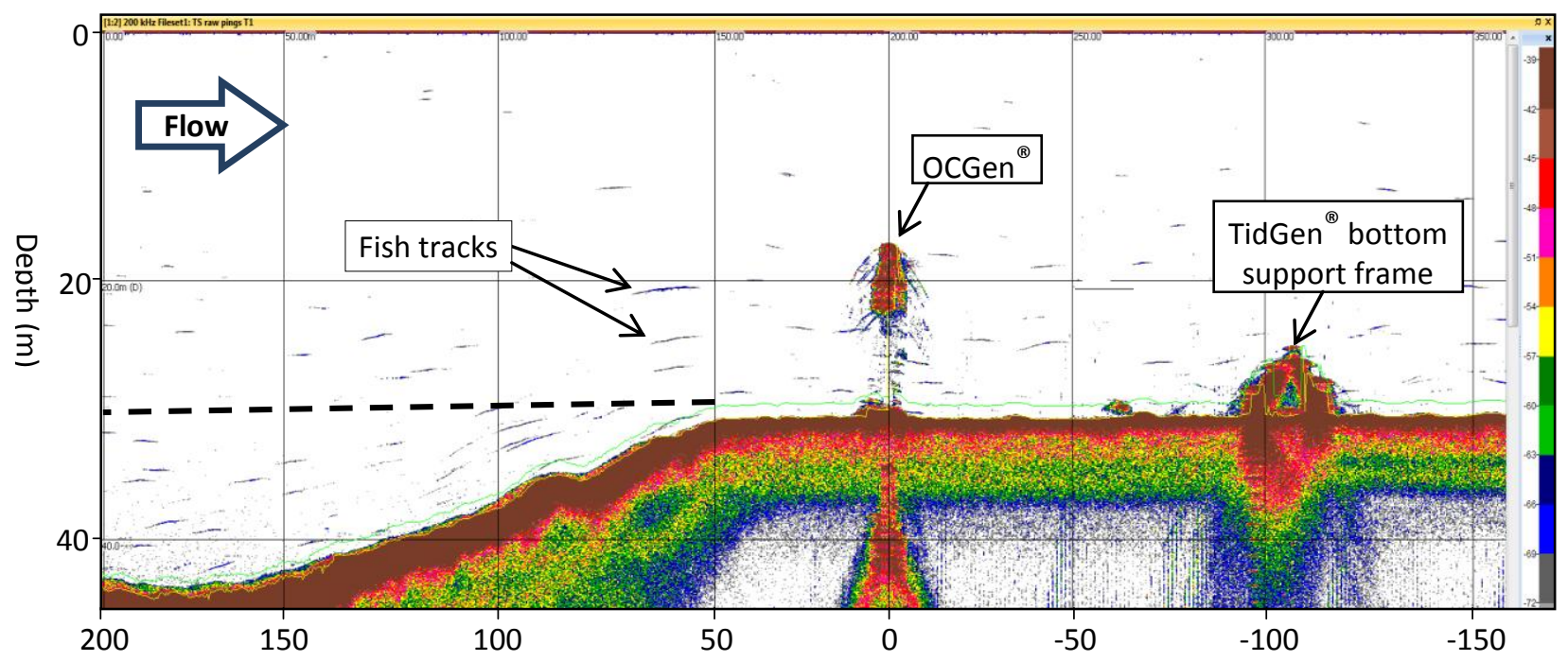

Fig. 3. One mobile transect over the OCGen ${ }^{\circledR}$ and the $\operatorname{TidGen}^{\circledR}$ bottom support frame during a flood tide. Fish tracks below the dashed line were excluded from analysis to ensure equal amounts of water sampled during the length of one transect.

As with stationary surveys, because the highest risk to fish would occur when the device is rotating, we focused analyses on data collected when the current velocity at the device was greater than $1 \mathrm{~m} \cdot \mathrm{s}^{-1}$, which is the velocity at which the device begins to rotate. Mobile hydroacoustic data were processed using Echoview ${ }^{\circledR}$ software, and fish were tracked using parameter settings shown in Table 1. The TS threshold used was lower than that for the stationary data collection in an effort to include more single targets, which improved our ability to track fish. To ensure the quality of detection, detected fish tracks were manually inspected for accuracy. Data exported for single 
194 target variables in fish tracks included location (GPS coordinates), TS, range from transducer, and angles of

195 deviation from the beam axes. Because boat motion could affect the results of single target detection and fish

196 tracking, a YEI Technology 3-Space Sensor was used to collect the IMU (inertial measurement unit) data (pitch,

197 roll, and yaw), which were used to calibrate the location and depth of each single target with 3D rotation matrices in

198 R (version 3.1.1, R Core Team, Vienna, Austria). The calibrated single targets in fish tracks were used to recalculate

199 the fish track variables, including location and depth.

200

201

Table 1

202 Parameters settings for single target and fish track detection in Echoview.

\begin{tabular}{lll}
\hline Process & Parameter & Value \\
\hline Single Target Detection & TS threshold & -70.00 \\
& Pulse length determination level (dB) & 6.00 \\
& Minimum normalized pulse length & 0.70 \\
& Maximum normalized pulse length & 0.50 \\
& Beam compensation model & Simrad LOBE \\
& Maximum beam compensation (dB) & 12.00 \\
& Maximum standard deviation of minor-axis angles & 10.00 \\
& Maximum standard deviation of major axis angles & 10.00 \\
\hline Fish Track Detection & Algorithm & $4 \mathrm{D}$ \\
& Data & $0.50 / 0.50 / 0.70$ \\
& Alpha (Major axis/Minor axis/Range) & $0.40 / 0.40 / 0.20$ \\
& Beta (Major axis/Minor axis/Range) & $1.50 / 1.50 / 0.10$ \\
Exclusion distance(m) (Major axis/Minor axis/Range) & $0.00 / 0.00 / 0.00$ \\
Missing ping expansion (\%) (Major axis/Minor axis/Range) & 30.00 \\
Weight & 30.00 \\
Major axis & 40.00 \\
Minor axis & 0.00
\end{tabular}

203

204

205

206

207

208

209

210

\subsection{Encounter probability model}

The probability that fish would encounter an MHK device was estimated from three components: 1) the probability of fish being at device-depth when a device was absent $\left.\left(p_{1}\right) ; 2\right)$ the probability of fish behavior changing to avoid the device between the control and the project site (separated by $1.6 \mathrm{~km}$ ) when an MHK device was present $\left(p_{2}\right)$; and 3$)$ the probability of fish behavior changing to avoid the device between the location of the stationary survey and the device $\left(p_{3}\right)$. Data from the stationary hydroacoustic surveys (from $2011-2013$ ) carried out near the 
$211 \operatorname{TidGen}^{\circledR}$ were used to estimate the first two probability components $\left(p_{1}\right.$ and $\left.p_{2}\right)$. Data collected from mobile

212 hydroacoustic surveys near the OCGen ${ }^{\circledR}$ in 2014 were used to estimate the third probability component $\left(p_{3}\right)$.

213 Because the device foils of the $\operatorname{TidGen}^{\circledR}$ and the OCGen ${ }^{\circledR}$ have a similar design and were located at similar depths,

214 the probability of fish encountering an MHK device can be calculated as

215

$$
p=p_{1} *\left(1-p_{2}\right) *\left(1-p_{3}\right)
$$

A Bayesian Generalized Linear Model (BGLM) [37] was used to estimate the probability of fish being at certain depths of interest in absence of the MHK device $\left.\left(p_{1}\right): 1\right)$ at the depth spanned by the entire TidGen $^{\circledR}(0.5-9.5$ $\mathrm{m}$ above the seafloor) and 2) at the depth spanned by the moving components (device foils) of the TidGen ${ }^{\circledR}(6.5-9.5$ $\mathrm{m}$ above the seafloor). Three factors that influence fish vertical distribution were considered: month, diel condition, and tidal stage. These factors have been shown to have significant influences on fish vertical distribution [7]. The model is given as

$$
y=\beta_{0}+\sum_{j=1}^{J_{1}} \beta_{1, j} x_{1, j}+\sum_{k=1}^{J_{2}} \beta_{2, k} x_{2, k}+\sum_{l=1}^{J_{3}} \beta_{3, l} x_{3, l}+\sum_{j=1}^{J_{1}} \sum_{k=1}^{J_{2}} \beta_{1 \times 2, j, k} x_{1 \times 2, j, k} .
$$

where $y$ denotes the probability of fish being at the depth of interest, $\beta_{0}$ denotes the baseline which is the overall mean probability of fish at a certain depth of interest, $\beta_{1}$ denotes the deflection of the baseline due to diel condition $\left(x_{1}\right)$ (i.e. how much $y$ changes when $x_{1}$ changes from neutral to category $j$ ), $\beta_{2}$ denotes the deflection based on the month $\left(x_{2}\right), \beta_{3}$ denotes the deflection based on the tidal stage $\left(x_{3}\right)$, and $\beta_{1 \times 2}$ denotes the interaction of diel condition and month. The baseline is constrained so that the deflection sums to zero across the level of $x$ [37] . The probability of different months, diel conditions, and tidal stages was estimated as the sum of the baseline and the deflection. The "rjags" package in R was used to fit BGLM [38]. The posterior distribution was computed based on 100,000 Markov Chain Monte Carlo simulations and a burn-in of 2,000 draws was removed from the beginning of the chain. From the posterior distribution, we calculated the mean and 95\% Highest Density Interval (HDI) [37].

Fish vertical distributions were compared between the project site and the control site, before and during the installation of the TidGen ${ }^{\circledR}$, to estimate $p_{2}$. Five hydroacoustic surveys were carried out in the presence of the bottom support frame of the TidGen ${ }^{\circledR}$ (2012: March and May) or the entire TidGen ${ }^{\circledR}$ (2012: August, September and 2013: March). The Hotelling's $T^{2}$ permutation test $[39,40]$ was used to examine if fish vertical distribution differed at the two sites before and during the deployment (package "Hotelling" in R; [41]). Because the device was fixed on 
the seafloor and the stationary hydroacoustic surveys took place from a moored boat, the distance between the device and the boat was different for ebb and flood tides. Since there was no information about the distance at which the device may affect fish behavior, the datasets were separated by tidal stage for each month and then compared between sites.

Mobile hydroacoustic data collected during flood tides were processed to estimate $p_{3}$. Because the seafloor sloped upward when the boat approached the device during the flood tide, fish tracks deeper than the dashed line (Fig. 3) were excluded to ensure equal amounts of water were sampled during the length of a transect. Since our focus was on the probability of fish encountering the MHK device, data collected upstream of the OCGen ${ }^{\circledR}$ were used to obtain the number of fish present. To investigate how fish avoided the OCGen ${ }^{\circledR}$, $\operatorname{transects}$ over the OCGen ${ }^{\circledR}$ were grouped together and fish tracks were binned into distance segments of $10 \mathrm{~m}$, with distance measured between the middle of fish tracks and the OCGen ${ }^{\circledR}$. The same method was used for control transects for comparison. If fish avoided the device, the number of fish tracks would decrease closer to the device. Fish could not be detected within $10 \mathrm{~m}$ of device due to its strong acoustic backscatter. Thus, a simple linear regression was fitted to fish counts between $10 \mathrm{~m}$ from the device and where the number of fish tracks began to decline. The predicted values from the model were used to estimate probability of fish avoidance. The confidence interval (CI) of $p_{3}$ was estimated using a bootstrap method. The total probability of fish encountering an MHK device was estimated by combining the three probability components using Equation 1. The delta method was used to estimate the confidence interval [42].

\section{Results}

The data collected at the project site in 2011 were used to illustrate the procedure, and results of the BGLM were used to estimate the probability $\left(p_{1}\right)$ of fish being at the depths of the entire device in the absence of a device.

258 From the BGLM, the posterior distribution of $p_{1}$ was given for the baseline, different months, diel conditions, and tidal stages (Fig. 4). The baseline is the annual probability of fish at the depth of the entire TidGen $^{\circledR}$ device $(0.5-9.5$ $\mathrm{m}$ above the seafloor) in 2011 (Fig. 4), which has a mean of 0.675 with 95\% HDI: $0.618-0.732$ (Table 2). The

261 probability was higher during the nighttime than during the daytime; nighttime: 0.750 (HDI: 0.682-0.817), daytime:

2620.588 (HDI: 0.501-0.676) (Table 2; Fig. 4a). The effect of the tidal stage was not significant for this dataset (Table

263 2; Fig. 4b). The effect of month was significant, especially in May when the probability was significantly lower than other months (0.240, HDI: 0.137-0.350) (Table 2; Fig. 4c). Baseline and associated environmental deflection 
posterior distributions of $p_{1}$ suggest a significant diel and month effect, but not a tidal effect (Fig. 4). The interactions of diel condition and month were significant in May, June, and November.

267
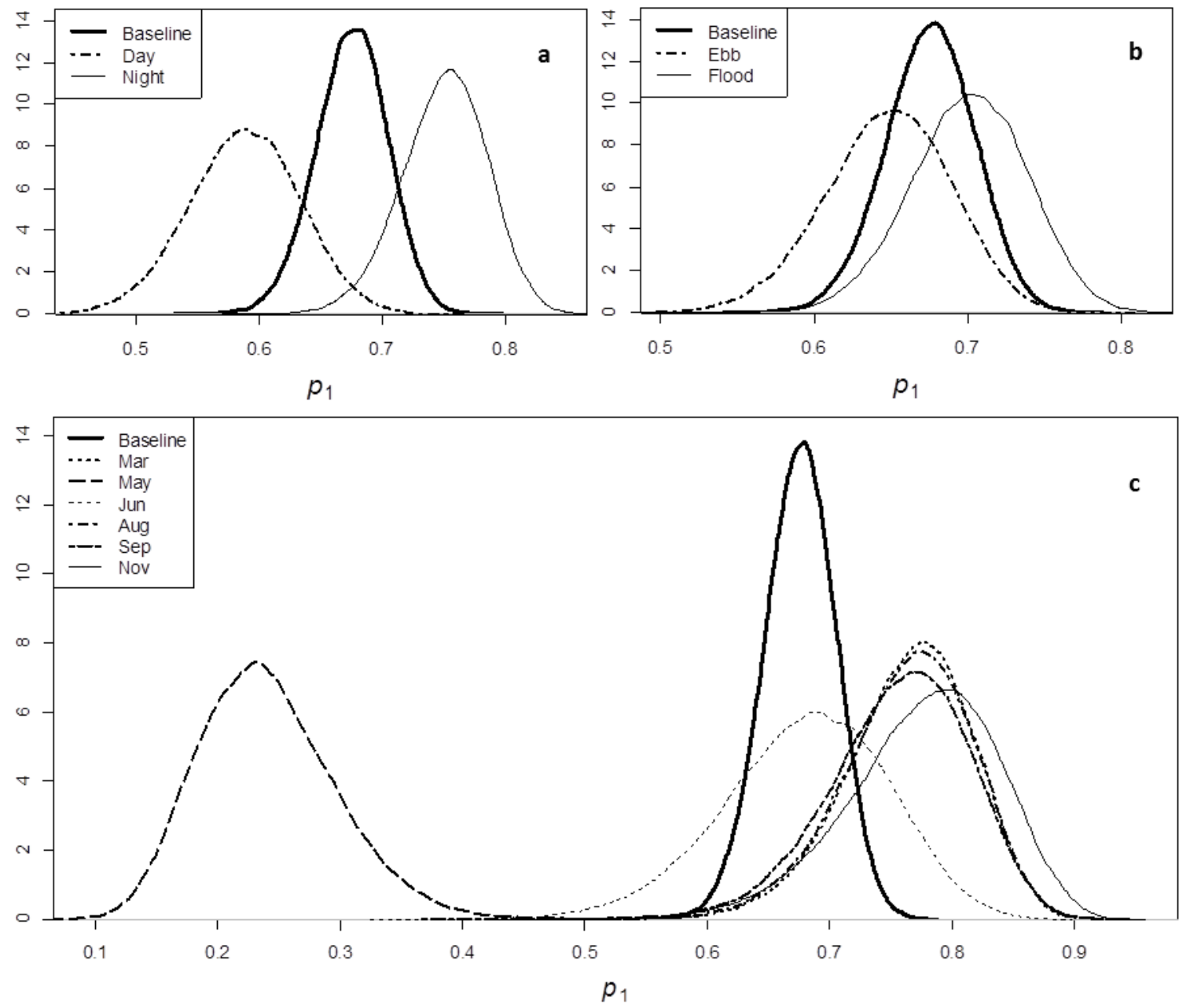

Fig. 4. The posterior distribution of the baseline with its HDI at the projected MHK deployment location in 2011 (prior to deployment). Horizontal axis is the probability of fish at the depth of the whole device. Top left panel denotes the deflection of diel condition. Top right panel denotes the deflection of tidal stage. Bottom panel denotes the deflection of month. 
Table 2

Probability $\left(p_{1}\right)$ of fish at depth of the whole device (0.5-9.5 m off the bottom) in absence of the MHK device with the 95\% HDI (High Density Interval) in 2011-2013. Overall mean is the baseline, which is the mean probability in each year. The probabilities in different months, diel and tidal conditions are also listed.

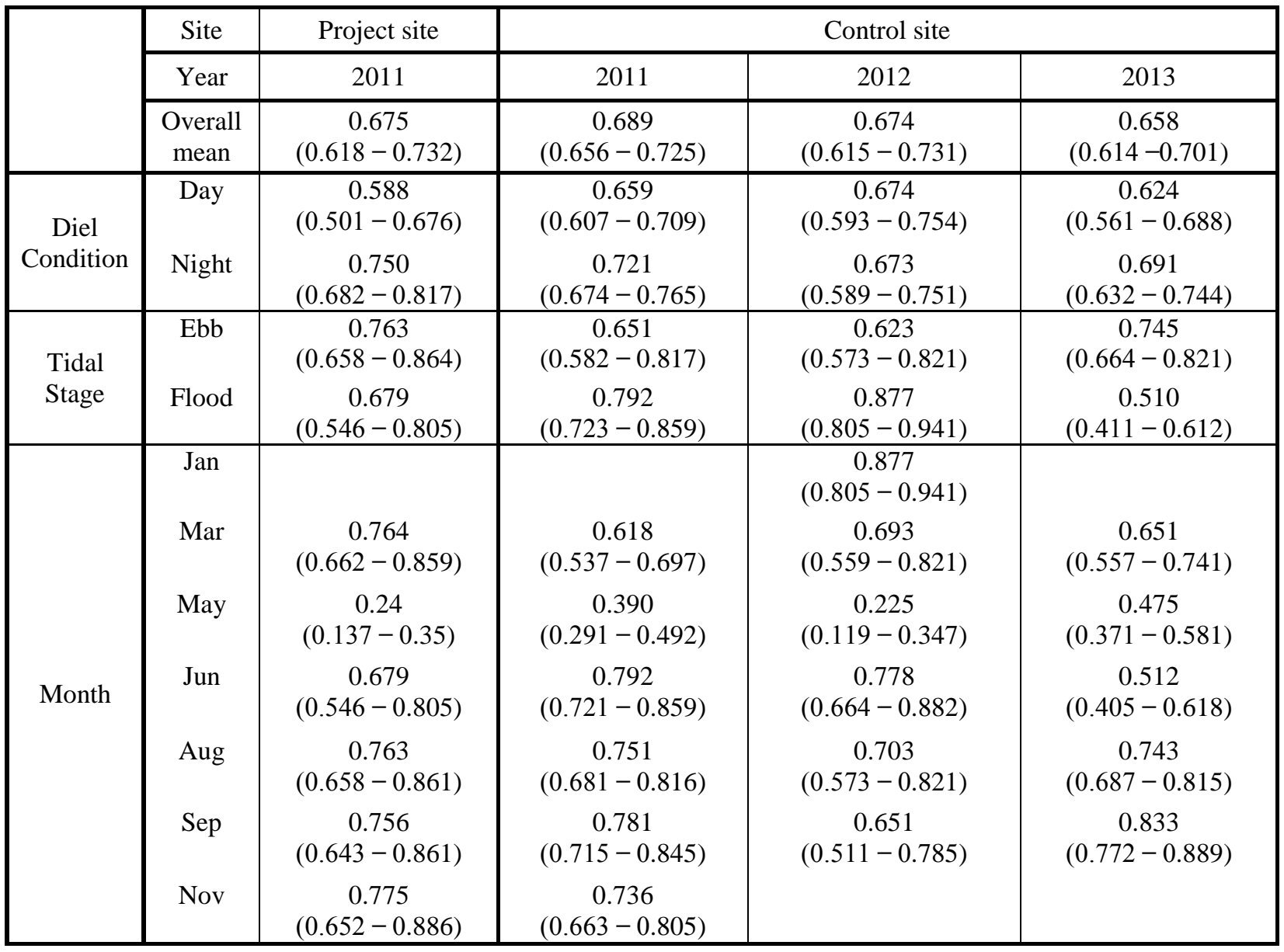

The probability of fish being at the depth of the whole TidGen ${ }^{\circledR}\left(p_{1}\right)$ was estimated for the whole year, different months, diel conditions, and tidal stages during 2011-2013 (Table 2). The estimated probabilities for year were not significantly different between sites and among years. The probabilities for year ranged from 0.658 to 0.689 during 2011-2013. The tidal stage was not a significant factor for data collected in 2011 and 2012; however it significantly affected probabilities in 2013. The diel condition was a significant factor for data collected at the project site in 2011. Generally speaking, the probability in May was significantly lower than other months by about $50 \%$. Table 3 gives the probability of fish being at the depth of the foils of the $\operatorname{TidGen}^{\circledR}\left(p_{1}\right)$. The estimated probabilities for year 
ranged from 0.079 to 0.093 and were not significantly different between sites and among years during 2011-2013.

The diel condition was a significant factor for data collected at the project site in 2011 and the control site in 2012.

The tidal stage and month were not significant factors in estimating the probability at the depth of the foils of the

$\operatorname{TidGen}^{\circledR}$.

Table 3

Probability $\left(p_{1}\right)$ of fish at depth of just the device foil (6.5-9.5 $\mathrm{m}$ off the bottom) in absence of the MHK device with the 95\% HDI in 2011-2013. Overall mean is the baseline, which is the mean probability in each year. The probabilities in different months, diel and tidal conditions are also listed.

\begin{tabular}{|c|c|c|c|c|c|}
\hline & Site & Project site & \multicolumn{3}{|c|}{ Control site } \\
\hline & Year & 2011 & 2011 & 2012 & 2013 \\
\hline & $\begin{array}{l}\text { Overall } \\
\text { mean }\end{array}$ & $\begin{array}{c}0.079 \\
(0.062-0.098)\end{array}$ & $\begin{array}{c}0.084 \\
(0.072-0.097)\end{array}$ & $\begin{array}{c}0.086 \\
(0.067-0.106)\end{array}$ & $\begin{array}{c}0.093 \\
(0.081-0.105)\end{array}$ \\
\hline Diel & Day & $\begin{array}{c}0.056 \\
(0.039-0.076)\end{array}$ & $\begin{array}{c}0.091 \\
(0.073-0.110)\end{array}$ & $\begin{array}{c}0.064 \\
(0.043-0.082)\end{array}$ & $\begin{array}{c}0.093 \\
(0.076-0.110)\end{array}$ \\
\hline Condition & Night & $\begin{array}{c}0.112 \\
(0.078-0.149)\end{array}$ & $\begin{array}{c}0.079 \\
(0.063-0.095)\end{array}$ & $\begin{array}{c}0.117 \\
(0.083-0.156)\end{array}$ & $\begin{array}{c}0.094 \\
(0.077-0.112)\end{array}$ \\
\hline Tidal & Ebb & $\begin{array}{c}0.089 \\
(0.052-0.133)\end{array}$ & $\begin{array}{c}0.0858 \\
(0.061-0.112)\end{array}$ & $\begin{array}{c}0.097 \\
(0.055-0.145)\end{array}$ & $\begin{array}{c}0.086 \\
(0.063-0.106)\end{array}$ \\
\hline Stage & Flood & $\begin{array}{c}0.064 \\
(0.047-0.105) \\
\end{array}$ & $\begin{array}{c}0.058 \\
(0.037-0.078) \\
\end{array}$ & $\begin{array}{c}0.079 \\
(0.042-0.121)\end{array}$ & $\begin{array}{c}0.103 \\
(0.079-0.129)\end{array}$ \\
\hline & Jan & & & $\begin{array}{c}0.079 \\
(0.043-0.122)\end{array}$ & \\
\hline & Mar & $\begin{array}{c}0.097 \\
(0.057-0.143)\end{array}$ & $\begin{array}{c}0.118 \\
(0.084-0.154)\end{array}$ & $\begin{array}{c}0.145 \\
(0.080-0.217)\end{array}$ & $\begin{array}{c}0.082 \\
(0.061-0.108)\end{array}$ \\
\hline & May & $\begin{array}{c}0.069 \\
(0.038-0.101)\end{array}$ & $\begin{array}{c}0.073 \\
(0.052-0.113)\end{array}$ & $\begin{array}{c}0.064 \\
(0.034-0.098)\end{array}$ & $\begin{array}{c}0.081 \\
(0.059-0.103)\end{array}$ \\
\hline Month & Jun & $\begin{array}{c}0.083 \\
(0.046-0.125)\end{array}$ & $\begin{array}{c}0.057 \\
(0.040-0.079)\end{array}$ & $\begin{array}{c}0.069 \\
(0.037-0.105)\end{array}$ & $\begin{array}{c}0.102 \\
(0.078-0.125)\end{array}$ \\
\hline & Aug & $\begin{array}{c}0.091 \\
(0.052-0.133)\end{array}$ & $\begin{array}{c}0.086 \\
(0.061-0.118)\end{array}$ & $\begin{array}{c}0.096 \\
(0.055-0.139)\end{array}$ & $\begin{array}{c}0.096 \\
(0.073-0.119)\end{array}$ \\
\hline & Sep & $\begin{array}{c}0.053 \\
(0.026-0.083)\end{array}$ & $\begin{array}{c}0.091 \\
(0.065-0.121)\end{array}$ & $\begin{array}{c}0.094 \\
(0.052-0.139)\end{array}$ & $\begin{array}{c}0.108 \\
(0.082-0.138)\end{array}$ \\
\hline & Nov & $\begin{array}{c}0.105 \\
(0.055-0.166)\end{array}$ & $\begin{array}{c}0.084 \\
(0.060-0.109)\end{array}$ & & \\
\hline
\end{tabular}

305

306

307

308

309

310

Fish behavior did not change between the control site and the project site when the device was deployed $\left(p_{2}=\right.$

0). The proportion of fish generally increased toward the seafloor at both the project and control sites except in May

(Fig. 5). By comparing fish vertical distributions between the project site and the control site, we found that vertical distributions were not significantly different in all months at the two sites before the device was deployed 
311 (Hotelling's $T^{2}$ test: $p>0.05$ ). When the support frame of the TidGen ${ }^{\circledR}$ or the whole device was in the water, from

312 March 2012 to June 2013, fish vertical distributions were not significantly different between the two sites

313 (Hotelling's $T^{2}$ test: $p$ values ranged from 0.145 to 0.594 ).

314
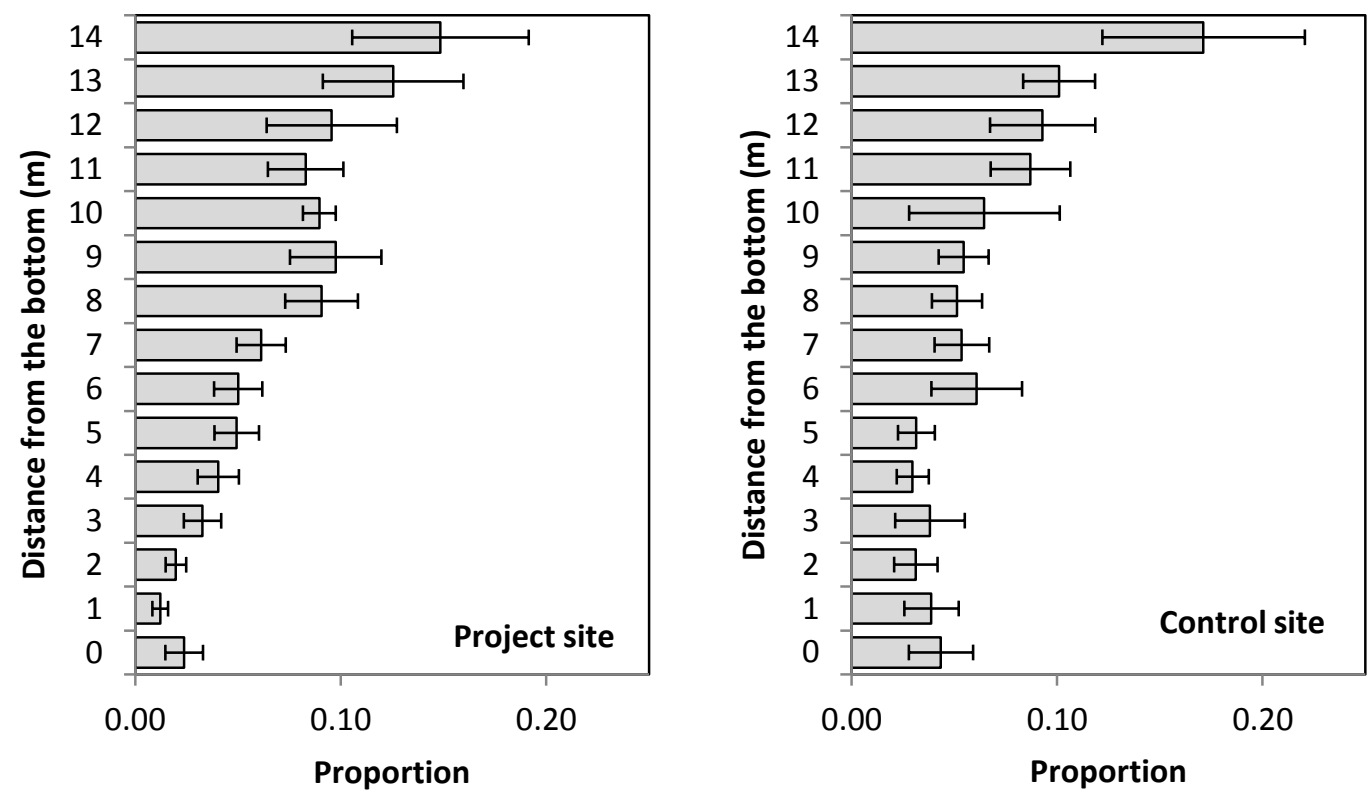

316
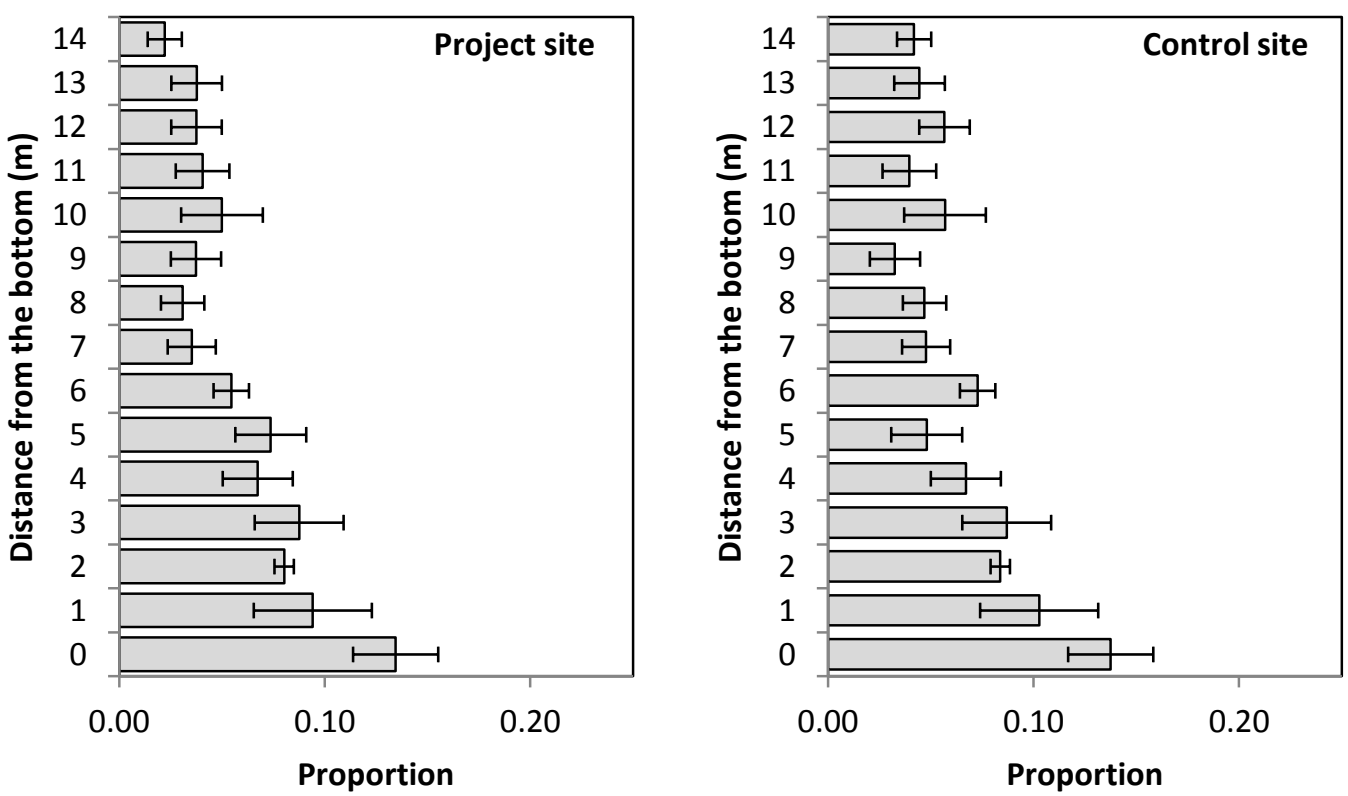

Fig. 5. Vertical distribution of fish during ebb tide in May (upper panels) and September (lower panels) 2012 surveys at project and control sites. Vertical axis is distance above bottom (m). Each horizontal bar represents the mean proportion of area backscatter $\left(s_{\mathrm{a}}\right)$ within each $1 \mathrm{~m}$ water column layer. Whiskers denote one standard error. Error bars are shown to indicate variance in depth bins over time, but were not used in statistical comparisons among sites. 
The BGLM was also used to estimate $p_{1}$ in 2012 at the project site (when the device was present). In 2012, the probability of fish being at the depth of the entire device was 0.652 (HDI: 0.543 to 0.762 ) at the project site, and the probability of fish being at the depth of the device foils was 0.090 (HDI: 0.069 to 0.113 ) at the project site. The estimated probabilities were similar between the project and control site in 2012 (Tables $2 \& 3$ ).

The number of fish in $10 \mathrm{~m}$ distance segments decreased nearer to the device (Fig. 6a), however, this decreasing trend was not observed for control transects (Fig. 6b). Fish numbers began decreasing $140 \mathrm{~m}$ upstream of the OCGen ${ }^{\circledR}$ when transects were over the device (Fig. 6a). A simple linear regression was fitted to the data from $10 \mathrm{~m}$ to $140 \mathrm{~m}$ upstream of the $\mathrm{OCGen}^{\circledR}$ (Fig. 6a). The fitted linear regression had intercept of 103.781, slope of 0.509, and $\mathrm{R}^{2}$ of 0.86 . Over all transects, there was a $37.2 \%$ (95\% CIs: $\left.[21.8 \%, 49.4 \%]\right)$ decrease in the number of fish
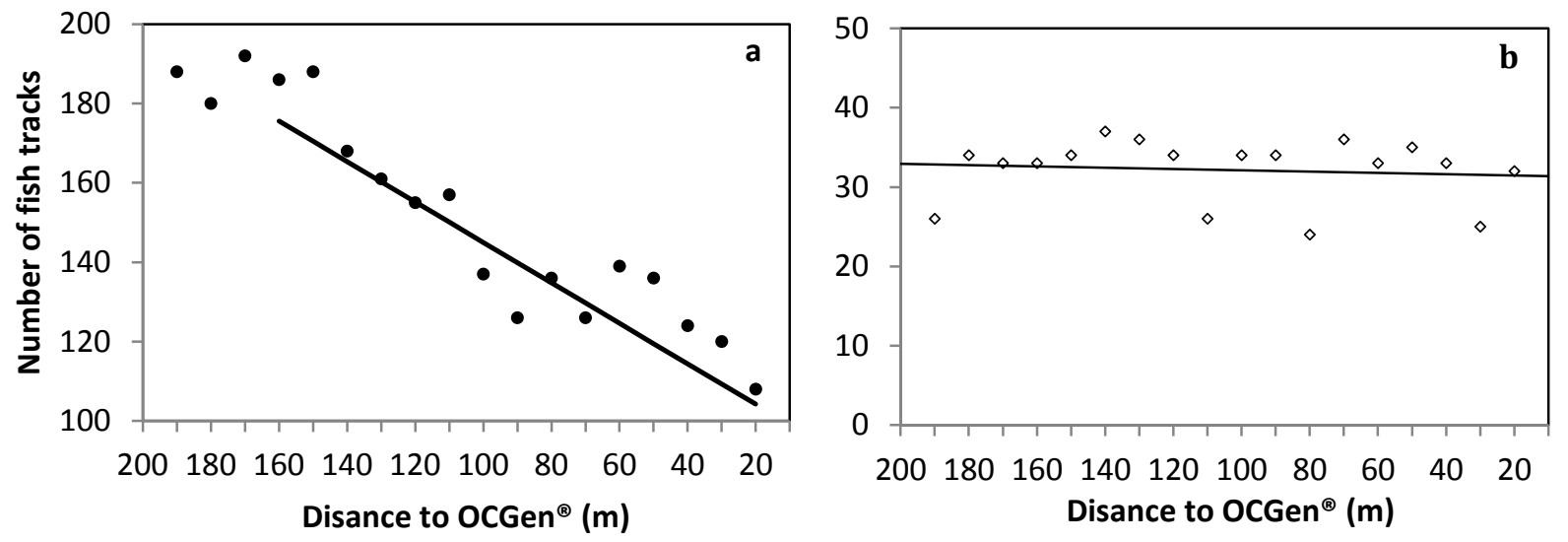

Fig. 6. Number of fish tracks upstream of the $\mathrm{OCGe}^{\circledR}$ device from transects over the device (left panel: linear regression line is $y=103.781+0.509 x, \mathrm{R}^{2}=0.862$ ) and control transects (right panel: linear regression line is $y=33.023-0.082 x, \mathrm{R}^{2}=0.012$ ).

The probability of fish encountering the device was estimated by combining the three probability components

using Equation 1. Because the mobile hydroacoustic surveys were only carried out in August 2014 and we wanted to estimate the highest risk, we chose to use the highest estimates of $p_{1}$ to estimate the probability of encountering the MHK device. The maximum values for $p_{1}$ were 0.689 for the probability that fish would be at the depth of the entire TidGen $^{\circledR}$, and 0.093 for the probability that fish would be at the depth of the device foils. The probability of avoiding between the control and project site $\left(p_{2}\right)$ was 0 and the probability of avoiding between the down-looking hydroacoustic survey site and $10 \mathrm{~m}$ from the device $\left(p_{3}\right)$ was 0.372 . In total, the probability of fish encountering the 
whole TidGen ${ }^{\circledR}$ was $0.432(95 \% \mathrm{CI}:[0.305,0.553])$ and the probability of fish encountering the device foils was 0.058 (95\% CI: [0.043, 0.073]).

\section{Discussion}

Our work has been the first opportunity to collect and apply empirical data to estimate the probability of fish encountering an MHK device under natural conditions. This, along with laboratory experiments [10,18] and in-situ observations $[4,20,43]$, is informing our understanding of fish interactions with MHK devices. In situ observations revealed fish evasion responses to MHK devices that suggest near field evasion $[4,20,43]$. Laboratory experiments inform near-field behaviors as well as survival rates during encounter $[10,18]$. In this paper, our objective was to examine fish avoidance of MHK devices by estimating the encounter probability of fish with an MHK device, the TidGen $^{\circledR}$. To estimate encounter probability, first we needed to know how many fish would spatially overlap with the MHK device. Our stationary hydroacoustic data allowed us to investigate the vertical distribution of fish with and without an MHK device, and how fish vertical distribution fluctuated on seasonal, diel, and tidal time scales. Mobile hydroacoustic data provided information on how and when fish responded to the device. Combining stationary and mobile hydroacoustic data, the encounter probability was estimated under natural conditions. Until now, this probability has been estimated only from laboratory experiments or modeling without empirical data.

Since the TidGen ${ }^{\circledR}$ was not available for all hydroacoustic surveys, the estimated probability of encounter consisted of a combination of empirical data at two similarly designed devices. The foil design and depth of the TidGen $^{\circledR}$ and the OCGen ${ }^{\circledR}$ were similar, so the data collected around the OCGen ${ }^{\circledR}$ were used with data collected around the TidGen ${ }^{\circledR}$. The TidGen ${ }^{\circledR}$ was bottom mounted and had a large support frame [7]. On the other hand, the OCGen $^{\circledR}$ was buoyed in mid-water, and moored to the seafloor with cables. The support frame of the TidGen ${ }^{\circledR}$ can affect the current, and this may result in underestimating the encounter probability due to fish detecting the larger device at a greater distance.

Our surveys were conducted with hydroacoustics, limiting our ability to isolate fish species within the mixed fish community of Cobscook Bay [44]. Vieser reported that Cobscook Bay has many pelagic and benthic fish species, and the five most abundant species captured by trawls were Atlantic herring (Clupea harengus), winter flounder (Pseudopleuronectes americanus), silver hake (Merluccius bilinearis), haddock (Melanogrammus aeglefinus), and longhorn sculpin (Myoxocephalus octodecemspinosus) [44]. Additionally, Atlantic mackerel 
(Scomber scombrus) are known to occur in this region during summer months [45] and their presence was verified using hook-and-line sampling during summer hydroacoustic surveys. Because the device foils were approximately 6 - $10 \mathrm{~m}$ above the seafloor, pelagic species might have a higher probability of encountering the foils than benthic species. Atlantic herring and Atlantic mackerel were therefore the most likely to be interacting with the tidal energy devices in Cobscook Bay.

Fish interactions with MHK devices have been characterized using other technologies which provided more species-specific or size-specific information [4,43], but they also had some limitations. Stereo-video underwater cameras, for example, were used to study MHK effects on swimming behavior of different fish species [43]. However, video cameras cannot detect fish at night without artificial lighting, which could alter the natural behavior of fish [46]. Multibeam DIDSON hydroacoustic cameras have the advantage of being able to observe fish during both day and night and provide estimates of fish size and shape [4], but fish species is difficult to discriminate. The detection range of high-resolution multibeam sonars (such as the DIDSON) is limited, and ranges that may be viewed with video cameras depend on water turbidity. Although our methods cannot separate species, we were able to apply hydroacoustics to describe general fish distribution under the limiting conditions of the environment with readily-available technology. Further assessment of device-animal interactions in these environments will be best accomplished using multiple approaches, e.g., split and single beam hydroacoustics, video, and multibeam hydroacoustics, until better technology is developed.

The probabilities of fish being at the depth of the whole device and device foils $\left(p_{1}\right)$ were similar at both the project and control sites during 2011-2012 (Tables 1 and 2). The variation in $p_{1}$ was not significant from 2011 to 2013 even though 2012 was an extraordinarily warm year in the Gulf of Maine [47], which suggested that fish vertical distribution was not affected by changes in temperature and associated fish abundance. Three factors (month, diel condition, and tidal stage) were included in the BGLM to estimate $p_{1}$. Although the three factors were not significant in all datasets, all were included so that we could compare the probabilities between sites and among years. Month was a significant factor for all datasets, due to less fish in the depth of the whole device in May (Table 2) when dense schools were present in middle and upper water column. In other months, fish density increased toward the bottom (Fig. 5). The diel difference was only significant at the project site in 2011 (Table 2). Generally, there was a higher probability of fish at the depth of the device at night, consistent with observations of Viehman et al. [7]. The tidal stage was only significant for data collected in 2013. The interaction of diel condition and month 
was significant for most of the dataset, which means the diel difference in fish vertical distribution was different among months. One possible explanation for this is the presence of different fish species in different months in Cobscook Bay. For example, Atlantic mackerel are only present in summer months $[44,45]$. Different species have different diel vertical migration behavior, which could result in the significant interaction of the diel condition and month observed here.

Mobile hydroacoustic surveys spanning $200 \mathrm{~m}$ upstream to $200 \mathrm{~m}$ downstream of the MHK device made it possible to monitor fish behavior from $200 \mathrm{~m}$ to $10 \mathrm{~m}$ upstream of the device. Fish numbers began to decrease when they were about 140 m upstream of the device. This decreasing trend was not observed for control transects. Although fish have different remote sensory systems including vision, hearing, the lateral line system, and olfaction, the MHK devices, which produce low-frequency sounds [48,49], might be first detected by hearing for some species

414 [50]. Atlantic herring is a hearing-sensitive species which may be able to detect an operating device hundreds of 415 meters away [19]. Device noise has been hypothesized to induce distinct avoidance by herring at 10-100 $\mathrm{m}$ distance 416 [19]. Thus, the avoidance by Atlantic herring and potentially other species may result in the decrease of fish tracks 417 approximately140 m upstream of the device. Atlantic mackerel, since they lack a swimbladder, are less sensitive to sound than herring [52]. As such, Atlantic mackerel may not avoid the device until they are closer than Atlantic herring. Since we analyzed hydroacoustic data collected with only one frequency ( $200 \mathrm{kHz})$, it is difficult to separate Atlantic herring from Atlantic mackerel and other species, so we cannot differentiate response distances of different species. Multi-frequency hydroacoustic system or stereo-video underwater cameras may help better understand the avoidance of different species in future studies.

Hammar et al. [19] categorized avoidance behavior as turning in a reverse direction (avoiding the device by swimming against the current, away from it) or a divergent direction (avoiding the device by slightly changing direction and swimming past it). In Cobscook Bay, captured Atlantic herring were a mix of larval and early juvenile life stages with the size range from $2.9 \mathrm{~cm}$ to $23.3 \mathrm{~cm}$ [44]. The TS of fish tracks ranged from $-70 \mathrm{~dB}$ to $-40 \mathrm{~dB}$ in the mobile hydroacoustic survey, corresponding to herring sizes less than $\sim 23 \mathrm{~cm}$ [53]. Larval and juvenile herring

428 of this size range are not strong enough to swim against a strong current [54], but may be capable of avoiding 429 obstacles by diverging slightly from the main current direction [53]. Atlantic mackerel caught at the project site averaged $20 \mathrm{~cm}$ and mackerel are stronger swimmers [55], which could allow them to avoid the device by swimming against the current (reverse direction) and turning in a divergent direction. Fish are known to avoid boats 
[55-57] and trawls by changing their direction horizontally and/or vertically [58,59]. To examine whether fish avoid an MHK device by sounding (vertically) or moving to the side (horizontally), we calculated the proportion of fish at the depth of the entire device relative to all fish in the whole water column and plotted it versus the distance to the OCGen $^{\circledR}$ (Fig. 8). The proportion did not change significantly throughout the $180-10 \mathrm{~m}$ distance upstream of the device. As such, the decrease in numbers between 140 and $10 \mathrm{~m}$ can only be explained by a change in horizontal position as they approach the device, rather than vertical change in position in the water column.

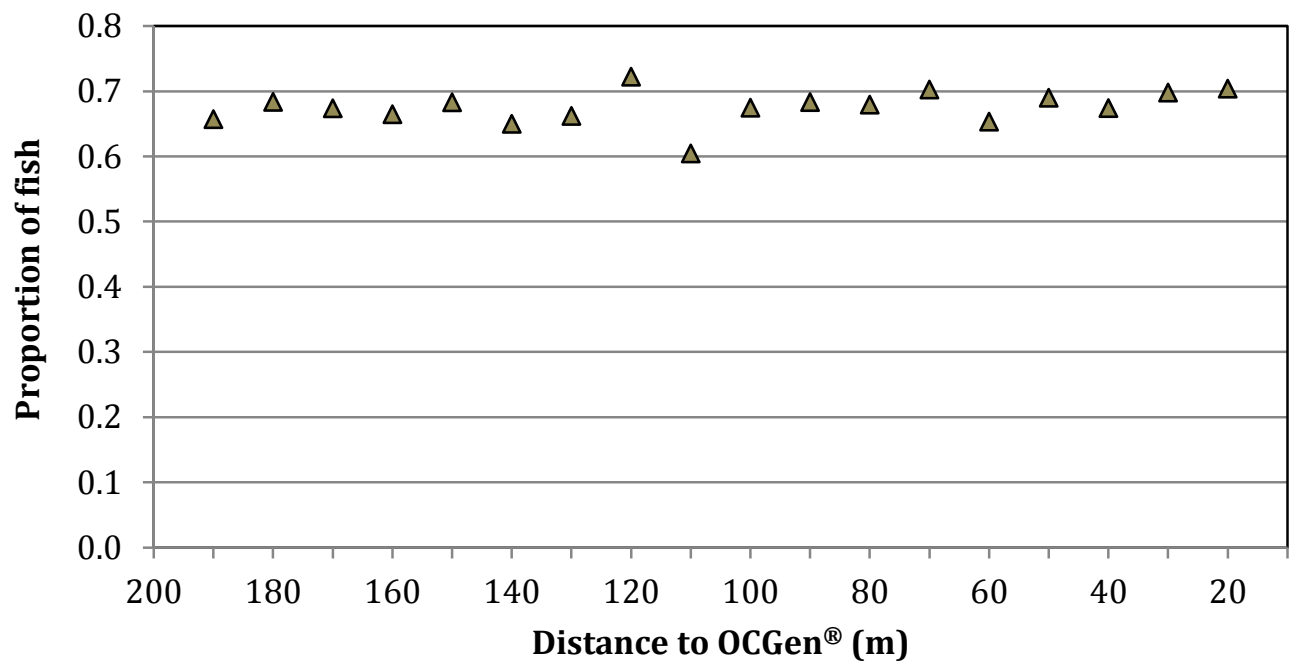

Fig. 8. Proportion of fish at the depth of the entire device (0-10 $\mathrm{m}$ above the seafloor) relative to fish in the whole water column in $10 \mathrm{~m}$ sections based on the distance to the OCGen ${ }^{\circledR}$.

By combining all three probability components, our results indicated that the probability of fish encountering the whole TidGen ${ }^{\circledR}$ was about 0.432 and the probability of fish encountering the device foils was 0.058 . Previously, fish have been observed evading a similar rotating device within very short distances $(0-3 \mathrm{~m} ;[4,43])$, as have fish in laboratory settings $[10,18]$. Therefore, the probability of fish entering the device upon encountering it will likely be lower. In this study, the horizontal extent of the MHK device is relatively small compared to the width of the entire Cobscook Bay, about $2.5 \%$ of the width of the Bay. If the whole of Cobscook Bay is considered (rather than the slice of water column associated with the beam we used for analysis), the probability of encountering one MHK device would be considerably smaller (i.e. 0.0015 by multiplying the probability of 0.058 by $2.5 \%$ ). However, commercial-scale development of arrays would occupy larger portions the Bay to generate more power and would need further consideration. Our results can be used to inform the effects of commercial arrays on fish in future. 
With the increasing development of tidal power, there are great concerns about collision risk of marine animals with devices. In the absence of conclusive observational data, collision risk has been explored through different models [6,19,21]. Although Hammar et al. [19] constructed a generic collision risk model to include base events, the collision risk is still poorly understood without empirical data. In this paper, we estimated the encounter probability of fish as close as $10 \mathrm{~m}$ upstream of an MHK device. Since the hydroacoustic data collected could not monitor fish behavior when they are closer than $10 \mathrm{~m}$ to the device, we could not estimate the events in the near-field, such as evasion and foil strike. However, some studies have demonstrated that fish can escape (evade) even when they are very close to a device foil by burst swimming $[4,10,19]$. Small fish like larval and juvenile herring may have higher survival because the pressure field around the foil may help them to pass around the foils, similarly to passive particles [6,60]. Even if struck, their small size relative to foil dimensions may also increase survival [61]. Studies in laboratories indicate that the probability of foil strike is low and survival rate was high even for fish entering a device $[10,18]$. However, data certainty and power of analysis are still questionable [18]. Although this study only estimated the probability of fish encountering one MHK device, the results allow a path to characterize fish responses to arrays of MHK devices and identify technological limitations that should be considered in future studies. Our results characterized some effects of MHK devices on fish, which can aid commercial developers in identifying mitigation options, for example, those required by the National Environmental Policy Act (NEPA) in the US.

\section{Acknowledgements}

We want to thank members of the Maine Tidal Power Initiative for their unwavering dedication to the responsible development of tidal power. Special thanks also go to ORPC for their partnership and access to devices and sites. We also want to thank Captain George Harris, Jr. and his crew for their assistance in the field, and many field volunteers for their interest and helping hands. This work is supported by the Department of Energy (DE-EE0003647 and DE-EE-0006384) and Argonne National Lab Contract \#3F-30561. The funding agents were not involved in the data collection, analysis and interpretation of data. The views expressed herein are those of the authors and do not necessarily reflect the view of ORPC or any of its subagencies.

\section{References}

[1] A.S. Bahaj, Generating electricity from the oceans, Renew. Sustain. Energy Rev. 15 (2011) 3399-3416. 
doi:10.1016/j.rser.2011.04.032.

[2] Y. Zhang, Z. Lin, Q. Liu, Marine renewable energy in China: Current status and perspectives, Water Sci. Eng. 7 (2014) 288-305. doi:10.3882/j.issn.1674-2370.2014.03.005.

[3] S. Waters, G. Aggidis, Tidal range technologies and state of the art in review, Renew. Sustain. Energy Rev. 59 (2016) 514-529. doi:10.1016/j.rser.2015.12.347.

[4] H.A. Viehman, G.B. Zydlewski, Fish interactions with a commercial-scale tidal energy device in the natural environment, Estuaries and Coasts. 38 Suppl 1 (2015) 1-12. doi:10.1007/s12237-014-9767-8.

[5] R. Charlier, C. Finkl, Ocean energy: tide and tidal power, Springer-Verlag, Berlin, 2009.

[6] P. Romero-Gomez, M.C. Richmond, Simulating blade-strike on fish passing through marine hydrokinetic turbines, Renew. Energy. 71 (2014) 401-413. doi:10.1016/j.renene.2014.05.051.

[7] H.A. Viehman, G.B. Zydlewski, J.D. McCleave, G.J. Staines, Using hydroacoustics to understand fish presence and vertical distribution in a tidally dynamic region targeted for energy extraction, Estuaries and Coasts. 38 Suppl 1 (2015) 215-226. doi:10.1007/s12237-014-9776-7.

[8] R. Pelc, R.M. Fujita, Renewable energy from the ocean, Mar. Policy. 26 (2002) 471-479. doi:10.1016/S0308-597X(02)00045-3.

[9] S. Amaral, G. Hecker, N. Pioppi, Fish passage through turbines: application of conventional hydropower data to hydrokinetic technologies. Tech. Rep. 1024638, EPRI (Electronic Power Research Institute), 2011.

[10] S. V. Amaral, M.S. Bevelhimer, G.F. Čada, D.J. Giza, P.T. Jacobson, B.J. McMahon, et al., Evaluation of behavior and survival of fish exposed to an axial-flow hydrokinetic turbine, North Am. J. Fish. Manag. 35 (2015) 97-113. doi:10.1080/02755947.2014.982333.

[11] J. McCleave, R. Kleckner, Selective tidal stream transport in the estuarine migration of glass eels of the American eel (Anguilla rostrata), ICES J. Mar. Sci. 40 (1982) 262-271.

[12] M. Castonguay, D. Gilbert, Effects of tidal streams on migrating Atlantic mackerel, Scomber scombrus L, ICES J. Mar. Sci. 52 (1995) 941-954.

[13] K.N. Lacoste, J. Munro, M. Castonguay, F.J. Saucier, J.A. Gagné, The influence of tidal streams on the prespawning movements of Atlantic herring, Clupea harengus L., in the St Lawrence estuary, ICES J. Mar. Sci. 58 (2001) 1286-1298. doi:10.1006/jmsc.2001.1118.

[14] D. Weihs, Tidal stream transport as an efficient method for migration, J Cons Int Explor Mer. 38 (1978) 92-99. doi:10.1093/icesjms/38.1.92.

[15] R.W. Rangeley, D.L. Kramer, Tidal effects on habitat selection and aggregation by juvenile pollock Pollachius virens in the rocky intertidal zone, Mar. Ecol. Prog. Ser. 126 (1995) 19-29.

[16] K. Jones, P. McGrath, K. Able, White Perch Morone americana (Gmelin, 1789) habitat choice and movements: comparisons between Phragmites-invaded and Spartina reference marsh creeks, J. Exp. Mar. Bio. Ecol. 455 (2014) 14-21.

[17] B. Polagye, B. Van Cleve, A. Copping, K. Kirkendall, Environmental effects of tidal energy development. NOAA Tech. Memo. F/SPO-116. U.S. Dept. Commerce, 2010.

[18] T. Castro-Santos, A. Haro, Survival and behavioral effects of exposure to a hydrokinetic turbine on juvenile Atlantic salmon and adult American Shad, Estuaries and Coasts. 38 Suppl 1 (2015) 1-12. doi:10.1007/s12237-013-9680-6.

[19] L. Hammar, L. Eggertsen, S. Andersson, J. Ehnberg, R. Arvidsson, M. Gullström, et al., A probabilistic model for hydrokinetic turbine collision risks: exploring impacts on fish, PLoS One. 10 (2015) e0117756. doi:10.1371/journal.pone.0117756.

[20] M. Broadhurst, S. Barr, C.D.L. Orme, In-situ ecological interactions with a deployed tidal energy device; an observational pilot study, Ocean Coast. Manag. $99 \quad$ (2014) 31-38. doi:10.1016/j.ocecoaman.2014.06.008. 
[21] B. Wilson, R.S. Batty, R. Daunt, C. Carter, Collision risks between marine renewable energy devices and mammals, fish and diving birds: Report to the Scottish Executive. Oban, Scotland: Scottish Association for Marine Science, 2006. http://nora.nerc.ac.uk/504110/1/N504110CR.pdf.

[22] C. Tomichek, J. Colby, M.A. Adonizio, M. Frisk, K. Dunton, D. Fox, et al., Tagged species detection: approach to monitoring marine species at marine hydrokinetic projects, in: Proc. 2nd Mar. Energy Technol. Symp., Seattle, USA, 2014.

[23] D.A. Brooks, Modeling tidal circulation and exchange in Cobscook Bay, Maine, Northeast. Nat. 11 (2004) 23-50. doi:10.1656/1092-6194(2004)11[23:MTCAEI]2.0.C0;2.

[24] M. Tarbotton, M. Larson, Canada ocean energy atlas (phase 1) potential tidal current energy resources analysis background. Prepared For: Canadian Hydraulics Centre, Ottawa, Ontario, Triton Consultants Ltd., 2006.

[25] M. Broadhurst, C.D.L. Orme, Spatial and temporal benthic species assemblage responses with a deployed marine tidal energy device: A small scaled study, Mar. Environ. Res. 99 (2014) 76-84. doi:10.1016/j.marenvres.2014.03.012.

[26] J.E. Broome, A.M. Redden, F.M. Keyser, M.J. Stokesbury, R.G. Bradford, Passive acoustic telemetry detection of Striped Bass at the FORCE TISEC test site in Minas Passage, Nova Scotia, Canada, in: Proc. 3rd Mar. Energy Technol. Symp., Washington, D.C., USA, 2015.

[27] G.D. Melvin, N.A. Cochrane, P. Fitzgerald, Evaluation of single and multi-beam sonar technology for water column target detection in an acoustically noisy environment. Can. Tech. Rep. Fish. Aquat. Sci. 2840, 2009.

[28] G.D. Melvin, N.A. Cochrane, A preliminary investigation of fish distributions near an in-stream tidal turbine in Minas Passage, Bay of Fundy. Can. Tech. Rep. Fish. Aquat. Sci. 3006, 2012.

[29] G.D. Melvin, N.A. Cochrane, Multibeam acoustic detection of fish and water column targets at high-flow sites, Estuaries and Coasts. 38 Suppl 1 (2015) 227-240. doi:10.1007/s12237-014-9828-z.

[30] J. Simmonds, D. MacLennan, Fisheries acoustics: theory and practice. 2nd ed., Blackwell Science, Oxford, 2005.

[31] W.A. Bennett, W.J. Kimmerer, J.R. Burau, Plasticity in vertical migration by native and exotic estuarine fishes in a dynamic low-salinity zone, Limnol. Oceanogr. 47 (2002) 1496-1507. doi:10.4319/lo.2002.47.5.1496.

[32] J.D. Neilson, D. Clark, G.D. Melvin, P. Perley, C. Stevens, The diel vertical distribution and characteristics of pre-spawning aggregations of pollock (Pollachius virens) as inferred from hydroacoustic observations : the implications for survey design, ICES J. Mar. Sci. 60 (2003) 860-871. doi:10.1016/S1054.

[33] O.P. Jensen, S. Hansson, T. Didrikas, J.D. Stockwell, T.R. Hrabik, T. Axenrot, et al., Foraging, bioenergetic and predation constraints on diel vertical migration: Field observations and modelling of reverse migration by young-of-the-year herring Clupea harengus, J. Fish Biol. 78 (2011) 449-465. doi:10.1111/j.1095-8649.2010.02855.x.

[34] D.A. Levy, Reciprocal diel vertical migration behavior in planktivores and zooplankton in British Columbia lakes, Can. J. Fish. Aquat. Sci. 47 (1990) 1755-1764.

[35] J. Kubecka, A. Duncan, Diurnal changes of fish behaviour in a lowland river monitored by a dual-beam echosounder, Fish. Res. 35 (1998) 55-63. doi:10.1016/S0165-7836(98)00059-9.

[36] K.G. Foote, H.P. Knudsen, G. Vestnes, D.N. MacLennan, E.J. Simmonds, Calibration of acoustic instruments for fish density estimation: a practical guide. ICES Coop. Res. Rep. 144, 1987.

[37] J.K. Kruschke, Doing Bayesian data analysis: A tutorial with R and BUGS, Academic Press, Burlinton, 2010.

[38] M. Plummer, rjags: Bayesian graphical models using MCMC, R Packag. (2011).

[39] H. Hotelling, The generalization Student's ratio, Ann. Math. Stat. 2 (1931) 360-378. 
574 [40] J. Lattin, J. Carroll, P. Green, Analyzing multivariate data, Duxbury, Pacific Grove, 2003.

575 [41] J.M. Curran, Package "Hotelling," (2015).

576 [42] A.C. Davison, Statistical models, Cambridge University Press, Cambridge, 2003.

[43] L. Hammar, S. Andersson, L. Eggertsen, J. Haglund, M. Gullström, J. Ehnberg, et al., Hydrokinetic turbine effects on fish swimming behaviour, PLoS One. 8 (2013) 1-13. doi:10.1371/journal.pone.0084141.

[44] J.D. Vieser, Collaborative research on finfish, their distribution, and diversity in Cobscook Bay, Maine, University of Maine, 2014.

[45] K. Athearn, C. Bartlett, Saltwater fishing in Cobscook Bay: Angler profile and economic impact. Maine Sea Grant Marine Research in Focus 6, 2008.

[46] K.L. Weinberg, P.T. Munro, The effect of artificial light on escapement beneath a survey trawl, Fish. Sci. 56 (1999) 266-274. doi:10.1006/jmsc.1999.0442.

586

[48] M.B. Halvorsen, T.J. Carlson, A.E. Copping, Effects of Tidal Turbine Noise on Fish Hearing and Tissues, Pacific Northwest National Laboratory, Sequim, WA, 2011.

[49] ORPC Maine LLC, Cobscook Bay tiday energy project: 2013 environmental monitoring report, 2014.

592

593

[50] A. Copping, L. Hanna, J. Whiting, S. Geerlofs, M. Grear, K. Blake, et al., Environmental Effects of Marine Energy Development around the World: Annex IV Final Report, 2013. www.ocean-energysystems.org.

595

596

597

598

599

600

601

602

603

604

605

606

607

608

609

610

611

612

613

614

615

616

617

[51] J. Astrup, Ultrasound detection in fish-a parallel to the sonar-mediated detection of bats by ultrasound-sensitive insects?, Comp. Biochem. Physiol. Part A. 124 (1999) 19-27.

[52] A. Hawkins, Underwater sound and fish behaviour, in: T.J. Pitcher (Eds.), The behaviour of teleost fishes, Springer, London \& Sydney, 1986.

[53] E. Ona, An expanded target-strength relationship for herring, ICES J. Mar. Sci. 60 (2003) 493-499.

[54] C.L. Jovellanos, D.E. Gaskin, Predicting the movements of juvenile Atlantic herring (IClupea harengus harengus) in the SW Bay of Fundy using computer simulation techniques, Can. J. Fish. Aquat. Sci. 40 (1983) 139-146.

[55] O.A. Misund, Avoidance behaviour of herring (Clupea harengus) and mackerel (Scomber scombrus) in purse seine capture situations, Fish. Res. 16 (1993) 179-194. doi:10.1016/0165-7836(93)90051-8.

[56] R. Vabø, K. Olsen, I. Huse, The effect of vessel avoidance of wintering Norwegian spring spawning herring, Fish. Res. 58 (2002) 59-77. doi:10.1016/S0165-7836(01)00360-5.

[57] A. De Robertis, C.D. Wilson, Walleye pollock respond to trawling vessels, ICES J. Mar. Sci. 63 (2006) 514-522. doi:10.1016/j.icesjms.2005.08.014.

[58] N.O. Handegard, K. Michalsen, D. Tjøstheim, Avoidance behaviour in cod (Gadus morhua) to a bottomtrawling vessel, Aquat. Living Resour. 16 (2003) 265-270. doi:10.1016/S0990-7440(03)00020-2.

[59] G. Rakowitz, M. Tušer, M. Říha, T. Jůza, H. Balk, J. Kubečka, Use of high-frequency imaging sonar (DIDSON) to observe fish behaviour towards a surface trawl, Fish. Res. 123-124 (2012) 37-48. doi:10.1016/j.fishres.2011.11.018.

[60] P.K. Chang, Separation of flow, Pergamon, New York, 1970.

[61] S.V. Amaral, G.E. Hecker, P. Stacy, D.A. Dixon, Effects of leading edge turbine blade thickness on fish strike survival and injury, in: Proc. Hydrovison, St. Louis, 2008. 